\title{
The Occurrence of the Preconditions for Social Exclusion in the Czech Republic: A Basis for the Planning of Social Prevention Services
}

\section{Eva Kovářová, Roman Vavrek ${ }^{1}$}

\begin{abstract}
Persisting social exclusion is one of the key issues the European Union Member States have to handle according to the headline targets of the Europe 2020 strategy. In the Czech Republic, more than 1 million people $-12.5 \%$ of the whole population lived in the year 2019 at risk of poverty or social exclusion. Between the years 2010 and 2019 , the monetary poverty rate oscillated around 10\%. Although these are one of the lowest rates among the EU Member States, reduction and elimination of social exclusion has still been a challenge for the Czech policy-makers due to the relatively constant rates of monetary poverty, as low incomes are generally recognized as one of the causes of social exclusion. The aim of the paper is to identify the occurrence of the preconditions for social exclusion in the Czech districts revealed in the inter-district comparison that is based on the multi-criterial evaluation of the socio-economic situation in these districts. Such evaluation can serve as a basis for the planning of social prevention services, which are regarded as the means of prevention and reduction of social exclusion. Our findings obtained with the use of the Multi-Criteria Decision Making technique reveal that the occurrence of the preconditions for social exclusion varies among LAU1 districts of the Czech Republic and that districts lying in two NUT3 regions are affected more than others. Individuals living there are more likely to be socially excluded, especially if this higher probability derived from the districts' socio-economic situation is accompanied with their individual poor skills, health, or family breakdown.
\end{abstract}

Keywords: Coefficient of Variance, Multi-criteria analysis, Multiple disadvantage, Poverty, Social exclusion, Social services

JEL Classification: A13, C39, H55

Received: 11 May 2020 /Accepted: 27 April 2021 / Sent for Publication: 8 June 2021

\footnotetext{
${ }^{1}$ VŠB - Technical University of Ostrava, Faculty of Economics, Department of Public Economics, Czech Republic; eva.kovarova@vsb.cz ORCID 0000-0002-1548-6889; roman.vavrek@vsb.cz ORCID 0000-0002-6047-9434

(C) 2021 by the authors; licensee Review of Economic Perspectives / Národohospodářský obzor, Masaryk University, Faculty of Economics and Administration, Brno, Czech Republic. This article is an open access article distributed under the terms and conditions of the Creative Commons Attribution 3.0 license, Attribution - Non Commercial - No Derivatives.
} 


\section{Introduction}

Poverty and social exclusion affect the individuals' well-being and limit their capabilities and functionings to live the life they have a reason to value (Sen, 2000). These days, the European Union considers poverty and social exclusion multidimensional issues the full picture of which is captured in three dimensions: monetary poverty, severe material deprivation and very low work intensity (European Commission, 2020a). In these terms, reduction of social exclusion is one of the challenges that the European Union (EU) wants to deal with in relation to the headline targets of the Europe 2020 strategy. By the end of the year 2020, the number of socially excluded individuals should have been reduced in comparison with the year 2008 by 20 million. The Czech Republic has followed social targets related to those declared at the EU level since its entrance to the EU. The national social policy programmes focus on social cohesion, full employment and social inclusion of those individuals who suffer from social exclusion in boarder terms. However, social exclusion is not as an urgent problem for the Czech Republic as it is for other EU Member States, if the EU methodology used for its measurement is applied. In 2019, 1,306 thousand individuals, $12.5 \%$ of the Czech population, lived at risk of poverty or social exclusion (European Commission, 2020b). This rate was the lowest among all the 27 EU Member States and fulfilled the national target concerning the reduction of the number of people living at risk of poverty or social exclusion formulated in relation to the Europe 2020 strategy.

Despite this optimistic result, social exclusion has still been a challenge for the Czech policy-makers because the number of people living in monetary poverty has oscillated around 1 million since 2008. It means that in relative terms around 9-10\% of the whole population have lived in conditions of monetary poverty. If the monetary poverty is seen as one of the preconditions for social exclusion, then it is evident that one of the primary causes of social exclusion has not been reduced in the Czech society regardless of the applied social policy programmes. Social services are understood as the standard social policy assistance applied to reduce or eliminate social exclusion and its risks in the Czech Republic. The Social Services Act (Act No. 108/2006 Coll.) legally frames the provision of social services and understands the basic terms as follows:

- social exclusion as the exclusion of individuals from a common life within the society and the impossibility of integration into such life due to an adverse social situation, and

- social services as the activity or set of activities ensuring assistance and support to individuals for the purposes of their social integration or prevention of their exclusion.

The act recognizes three basic types of social services - social counselling, social care services and social prevention services. The last type is focused primarily on providing help to avoid social exclusion of individuals facing critical social situation. Social prevention services help them overcome this situation and protect the society against the occurrence and spread of poverty and social exclusion.

Responsible planning of the social services supply which will be able to reduce or eliminate social exclusion and its risks can be based on two approaches: methods of the community planning, or objective verification of the risks and preconditions for social exclusion at the individual, community or regional level. However, economic theory and practical social policy consider social prevention services as services with supplier-induced 
demand (Mertl, 2007), which makes the community planning impossible to apply. Therefore, planning of the social prevention services should be based on the analysis of existing socio-economic preconditions for social exclusion and thus its higher risks, in terms of the presence of linked socio-economic problems, regarded as the potential causes of social exclusion.

The aim of the paper is to identify the occurrence of the preconditions for social exclusion in the Czech districts revealed in the inter-district comparison that is based on the multicriterial evaluation of the socio-economic situation in these districts. The socio-economic situation is assessed using a set of socio-economic indicators capturing economic and social dimensions of social exclusion and its risks. The paper follows the European discourse of social exclusion. Therefore, the primary causes of social exclusion are seen in the exclusion from the labour market, unequal distribution of resources and risky behaviour of socially excluded individuals. An analysis is done for all LAU1 districts lying in 14 NUT3 regions of the Czech Republic for the years 2011 and 2016. With the research, we would like to show the Czech policy-makers the districts in which public authorities should redesign the supply of social prevention services due to persisting social exclusion or its preconditions and risks.

\section{Theoretical background}

Exclusion from the labour market, low incomes and thus monetary poverty are considered the main causes of social exclusion in its economic interpretation in the EU Member States. In general, poverty is a situation of material deprivation faced by individuals. Poverty can be defined as a systematic failure in the distribution of wealth, or a behavioural failure of those who fail to acquire it. Poverty concerns with distributive issues and focuses on statutes disadvantage (Dean, 2016). Poverty as a concept is primarily connected to incomes and expenditures (Room, 1995). Being poor means being identified as an individual lacking material assets (Estivill, 2003). The concept of social exclusion refers to poverty while also paying attention to the processes by which poverty or disadvantage occur. If poverty is viewed as the absence, lack or denial of advantage (Dean, 2016), then social exclusion is understood as the multidimensional disadvantage (Room, 1995).

In general, social exclusion is viewed as covering a remarkably wide range of social and economic problems (Sen, 2000) because people may be excluded from a livelihood; secure, permanent employment; earnings; property, credit or land; housing; the minimal or prevailing consumption level; education, skills and cultural capital; the benefits provided by participation in democratic process; public goods; the nation or the dominant race; the family and sociability; humane treatment, respect, personal fulfilment and understanding (Silver, 1994). Being socially excluded means suffering from a combination of linked problems such as unemployment, poor skills, low incomes, poor housing, high crime environment, poor health and family breakdown (Social Exclusion Unit, 2001). However, being socially excluded also means not being able to participate in basic social activities of a society (Chakravarty, D'Ambrosio, 2006).

Conceptually, social exclusion affects individuals (Daly et al., 2016) or whole communities or localities (Harding et al., 2009; Barnes et al., 2009). Social exclusion is usually interpreted in terms of its multidimensional, dynamic and relational (Room, 1995) or collective (Milar, 2007) nature. At individual level, exclusion is related to the dissatisfaction 
or unease felt by individuals who face situations in which they cannot achieve their objectives for themselves or their loved ones (Estivill, 2003). However, social exclusion is not only about individual living but also about the collective resources in the neighbourhood or community (Milar, 2007). Since the 1990s, the European discourse of social exclusion has been based on Silver's (1994) and Levites's (1998) approaches. At the EU level, social policy targets can be understood with respect Levites's three political discourses where social exclusion is understood as the consequence of: I. Labour market exclusion; II. Unequal distribution of resources; III. Behaviour of socially excluded individuals. Since social exclusion is considered multidimensional, its several dimensions can be recognized as for example the economic, social, political, community or spatial dimensions of social exclusion. (Mareš, Sirovátka 2008). They related them to the socioeconomic status of socially excluded individuals, their full participation in social life or the preconditions existing in the areas where the individuals live.

With respect to the European discourse, integration to the labour market and reduction of monetary poverty through high incomes and social benefits are considered the basic ways of including socially excluded individuals back to the society. Furthermore, social services can be used as well to improve the well-being of individuals facing or being at risk of some forms of social exclusion. Social services are the vital means that help to meet the EU objectives concerning the social, economic and territorial cohesion, high employment, social inclusion and economic growth. The European Commission declares that every citizen, especially the most disadvantaged ones, should be able to count upon quality social services that also include needs-based personal targeted services focused on social inclusion and labour market integration. The access to quality services belongs to the active inclusion policies in practical terms (European Commission, 2019).

Public authorities in the EU Member States play an important role in the delivery and thus planning of social services. In the case of social prevention services, planning of the supply is complicated by the defining characteristics of the demand, formulated by Víšek and Průša (2012) as follows: I. Needs are unpredictable in advance because of unpredictable social events leading to the social exclusion. II. Needs are often latent and are revealed only when the services are offered. III. Information asymmetry exists between demand and supply subjects. Therefore, the demand for social prevention services is close to supplier-induced demand. Providers of social services are considered agents who are able to define needs of individuals and thus the demand for services that help these individuals to overcome or avoid social exclusion, or agents who influence the individuals positively to create additional (induced) demand.

A key role in the planning of social services supply is seen in the objective evaluation of the socio-economic status/situation of individuals, communities or regions with the use of a defined set of criteria. This evaluation creates a background for the planning of the social services supply in such a kind, form and quantity in which it will be able to reduce or eliminate social exclusion, its preconditions and thus its higher risks. This objective evaluation can be based on: I. Macrosocial analysis of occurrence of certain risks (Víšek, Průša, 2012); II. Analysis of the occurrence of combination of linked socio-economic problems (Oroyemi et al., 2009; Social Exclusion Unit, 1997), III. Analysis of individual and community factors of social exclusion (McCrystal et al., 2001). All mentioned authors recommend the use of an analysis dealing with a set of socio-economic indicators that can capture the existing social exclusion, its preconditions, its risks and causes. As 
the social exclusion is a relative concept, it can be revealed only with the use of interindividual or inter-community (or inter-regional) comparison done with the aim to identify the relative multiple disadvantage of the assessed object in relation to others.

\section{Material and methods}

The aim of the paper is to identify the occurrence of the preconditions for social exclusion in the Czech districts revealed in the inter-district comparison based on the multi-criterial evaluation of the socio-economic situation in these districts. The socio-economic situation is assessed using a set of socio-economic indicators capturing economic and social dimensions of social exclusion and its preconditions. The set of used socio-economic indicators is specified with respect to the research studies introduced above.

We deal with seven socio-economic indicators with data available only at the level of NUTS3 regions (see Table 1) and fifteen at the level of LAU1 districts (see Table 2). The set of indicators is defined according to the literature review and the European discourse concerning social exclusion. An analysis is done for all 77 LAU1 districts lying in 14 NUT3 regions of the Czech Republic for the years 2011 and 2016.

\section{Table 1. List of indicators followed for the NUTS3 regions}

\begin{tabular}{cl} 
Indicator & \multicolumn{1}{c}{ Description } \\
\hline $\mathrm{R}_{1}$ & Annual GDP per capita (in thousand CZK) \\
$\mathrm{R}_{2}$ & Median of gross wages in private sector per capita per month (in thousand CZK) \\
$\mathrm{R}_{3}$ & Annual net disposable income of households per capita (in thousand CZK) \\
$\mathrm{R}_{4}$ & Number of users of low-threshold facilities for children and youth per 1,000 inhabitants \\
$\mathrm{R}_{5}$ & Number of persons under the age of 18 being prosecuted or investigated per 1,000 inhab- \\
& itants \\
$\mathrm{R}_{6}$ & Number of the university graduates (living in the region) in the given year per 1,000 inhab- \\
& itants \\
$\mathrm{R}_{7}$ & Number of early school leavers in the given year per 1,000 inhabitants \\
\hline
\end{tabular}

Source: own processing.

Because of the applied methods, we assume that the values of the indicators $R_{1}-R_{7}$ are the same for all districts lying in one NUT3 region.

The technique of Order Preference Similarity to the Ideal Solution (TOPSIS) in combination with the Coefficient of Variance method (CV) are the statistical methods that allow the assessment and comparison of the Czech districts according to the defined set of socio-economic indicators (calculated based on Vavrek, 2019; Vavrek, Bečica, 2020). Each socio-economic indicator is a criterion used for the assessment of the socio-economic situation in one district with the 23 criteria describing the overall socio-economic situation in one district. Therefore, we work with a 77x23-criterial matrix. The application of CV-TOPSIS technique allows us to identify districts with relatively higher or with relatively lower occurrence of preconditions for social exclusion and thus its higher risks. We complement the results obtained using the CV-TOPSIS technique with the Moran's Index calculation (MI) based on Slávik et al., 2011, and local indicators of spatial association (LISA). This helps us to identify the so-called cold spots - the districts with relatively worse socio-economic situation and similar neighbouring districts. During our data processing, we apply some other methods, such as Shapiro-Wilk test (SW), Mann-Whitney 
$\mathrm{U}$ test (U), Kolmogorov-Smirnov test (K-S), and Kendall rank coefficient $\left(\mathrm{r}_{\mathrm{K}}\right)$. The dataset was taken from the public databases by the Czech Statistical Office, the Ministry of Education, Youth and Sports, and the Ministry of Labour and Social Affairs of the Czech Republic. The data was extracted and processed during January and February 2019.

\section{Table 2. List of indicators followed for the NUTS3 regions}

\begin{tabular}{|c|c|}
\hline Indicator & Description \\
\hline $\mathrm{D}_{1}$ & Amount of child allowances per 1,000 inhabitants (in thousands CZK) \\
\hline$D_{2}$ & Amount of housing allowances per 1,000 inhabitants (in thousands CZK) \\
\hline$D_{3}$ & $\begin{array}{l}\text { Share of inhabitants living in towns having less than } 3,000 \text { inhabitants in total number of in- } \\
\text { habitants }\end{array}$ \\
\hline $\mathrm{D}_{4}$ & $\begin{array}{l}\text { Share of inhabitants living in towns having more than } 20,000 \text { inhabitants in total number of } \\
\text { inhabitants }\end{array}$ \\
\hline$D_{5}$ & Number of children born to mothers under the age of 19 per 1,000 inhabitants \\
\hline $\mathrm{D}_{6}$ & Number of children born at least as the fourth child in a family per 1,000 inhabitants \\
\hline $\mathrm{D}_{7}$ & Number of children born to unmarried mothers per 1,000 inhabitants \\
\hline $\mathrm{D}_{8}$ & Average number of inhabitants with sickness insurance per 1,000 inhabitants \\
\hline$D_{9}$ & Number of calendar days of temporary incapacity to work per 1,000 inhabitants \\
\hline$D_{10}$ & Total number of registered job seekers per 1,000 inhabitants \\
\hline$D_{11}$ & Total number of registered job seekers under the age of 24 per 1,000 inhabitants \\
\hline $\mathrm{D}_{12}$ & Total number of job seekers registered for more than 12 months per 1,000 inhabitants \\
\hline$D_{13}$ & Number of divorces per 1,000 inhabitants \\
\hline$D_{14}$ & Number of inhabitants receiving pensions per 1,000 inhabitants \\
\hline $\mathrm{D}_{15}$ & Average pension per capita per month (in thousand CZK) \\
\hline$D_{16}$ & Number of registered crimes per 1,000 inhabitants \\
\hline
\end{tabular}

Source: own processing.

\section{Results}

Our analysis and assessment aim to identify the occurrence of the preconditions for social exclusion in Czech district in two following years (2011 and 2016). We structure our analysis, and thus presentation of our results and findings as follows:

I. We assess the socio-economic situation according to the defined criteria in all districts for the year 2011, then for the year 2016. In both years, we first pay attention to the variability of the followed socio-economic criteria due to the differing values among Czech districts. Then, for both years, we evaluate the values of relative distance to Positive Ideal Solution $\left(c_{i}\right)$ calculated with the use of the CV-TOPSIS technique for all LAU1 districts. Finally, we order the districts according to the achieved values of $c_{i}$. We recognize two extreme groups of districts: a. Districts where the socio-economic situation in terms of the preconditions for social exclusion is the worst (districts with the lowest values of $c_{i}$ ). b. Districts where the socio-economic situation in terms of the preconditions for social exclusion is the best (districts with the highest values of $c_{i}$ ).

II. We compare our findings for both years to demonstrate if any progress in the socioeconomic situation in the Czech districts is visible between years 2011 and 2016.

III. We calculate the Moran's Index to identify the cold spots in the Czech Republic.

IV. Finally, we explain the complex results and findings of our analysis and formulate a recommendation for the Czech policy-makers. 
Districts' assessment for the year 2011

First, we examine the value range of the socio-economic criteria observed in all the Czech districts (Figure 1). High variability is observed in the case of three LAU1 indicators $\left(\mathrm{D}_{1}\right.$, $\mathrm{D}_{2}, \mathrm{D}_{8}$ ) and one NUT3 indicator (R1). However, the range in absolute terms is not accompanied by the range in relative terms. The coefficient of variation for the $\mathrm{D}_{1}$ indicator is $25.95 \%$, which we consider standard in comparison with another indicator $\left(\mathrm{V}_{\mathrm{D} 4}=\right.$ 91.10\%; $\mathrm{V}_{\mathrm{D} 15}=2.17 \%$ ). $\mathrm{R} 1$ differentiates significantly from the other indicators but its range is influenced by Prague, the region with the highest GDP p.c. With regard to our preliminary data processing, we identify the statistically significant differences between the values of socio-economic indicators capturing the presence of social exclusion or the occurrence of its preconditions and risks. We expect the significant differences in the multi-criterial assessment of the socio-economic situation in the Czech districts visible complexly through the $\mathrm{c}_{\mathrm{i}}$ values.

Figure 1. Structure of the input indicators given for the year 2011
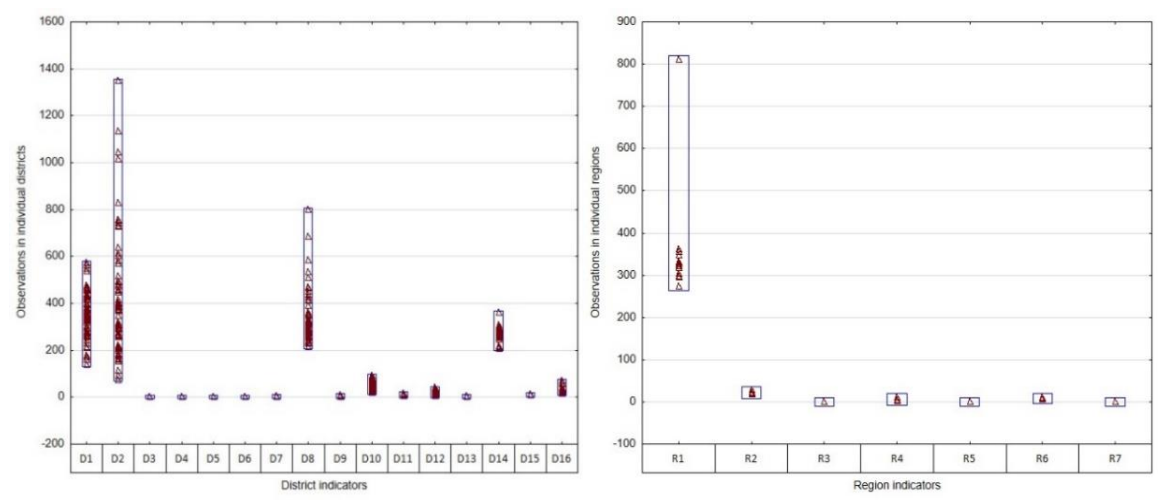

Source: own data processing

Figure 2 shows complex results calculated using the CV-TOPSIS technique. They have negative skewness $\left(\gamma_{2011}=-1,108\right)$, which indicates larger number of districts with aboveaverage $c_{i}$ values. From the point of view of social exclusion risks and preconditions, we interpret this fact in positive terms. The results are determined by three outliers $\left(c_{i}\right.$ values for districts of Karvina, Most, Ostrava-City), which led to the rejection of the hypothesis for normal distribution $(\mathrm{SW}=0.881 ; \mathrm{p}<0.01)$, higher range $(\mathrm{R}=0.366)$ and also higher variability $\left(\mathrm{V}_{2011}=14.81 \%\right)$. We objectively evaluate these three districts as being affected by a combination of linked socio-economic problems, which reveals us the existence of a relative disadvantage in terms of social exclusion and its higher risks for individuals living there as compared to the other districts. Individuals living there have to face more risks and they are more likely to live in conditions of social exclusion. 
Figure 2. Results of the CV-TOPSIS technique for the year 2011

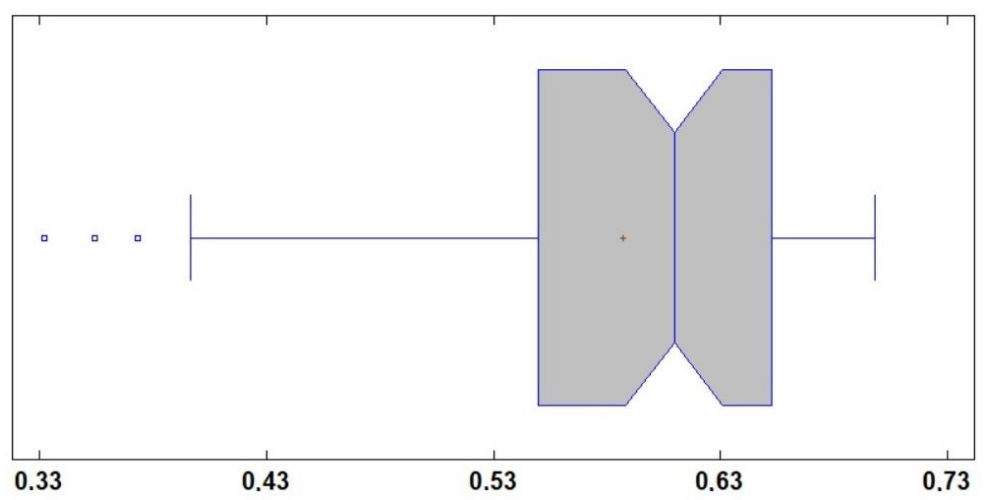

Source: own data processing

Overall, ten districts identified as the districts with the lowest occurrence of the preconditions for social exclusion are placed at $7.43 \%$ of the range of the complex results, which means that the differences in $c_{i}$ values of these ten districts are less significant than in the case of the districts with lower $c_{i}$. This reveals that the differences existing within the group of the best ten districts are caused by differing values of one or two indicators and indicates problems that do not have an impact on all the individuals living there. On the other hand, $40 \%$ of the results' variability ( 0.146 of the relative distance to PIS) is assigned to the districts assessed as worse. According to our findings, we can observe higher differences with lower $c_{i}$ values. It means that the partial improvement of socio-economic indicators covering social exclusion and its preconditions can lead, ceteris paribus, to a significantly improved overall assessment only in the case of districts with higher values of $c_{i}$. It also means that we cannot assume there to be an improvement of socio-economic situation in districts with worse assessment in short-term period. This is not an optimistic finding from the perspective of individuals living there.

Figure 3. CV-TOPSIS technique results for the year 2011

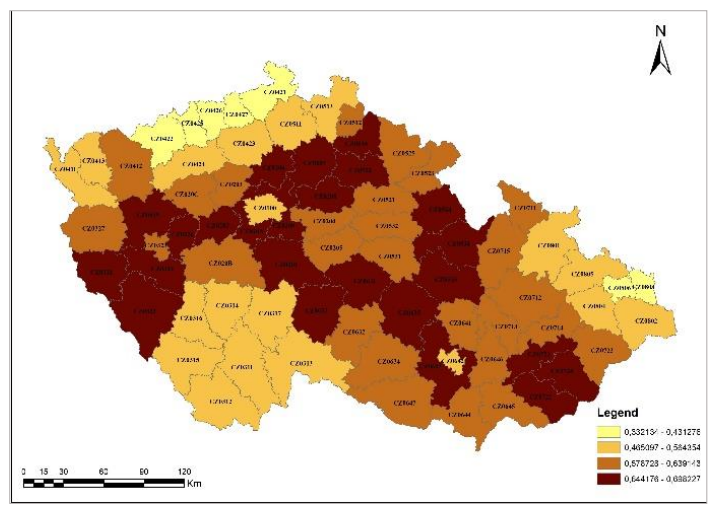

Source: own data processing 
Districts localized in the Plzen Region (districts of Plzen-South, Domazlice, Rokycany, Plzen-North), Vysocina Region (Pelhrimov), or in the Zlin Region (Uherske Hradiste) are identified as districts with higher values of $c_{i}-$ we consider them districts with relatively lower occurrence of social exclusion and its preconditions and risks (Figure 3.). It means that individuals living there have a relative advantage in terms of social inclusion. Districts of Most, Usti nad Labem or Chomutov in the Usti Region, and Ostrava-City or Karvina in the Moravian-Silesian Region belong among the worst districts. It means that these districts suffer from social exclusion or higher occurrence of its preconditions, which has an impact on material and also immaterial well-being of the individuals living there. They are more likely to be socially excluded especially if their well-being is also affected by unemployment, low income, dependency on state benefits; and even more if they have low skills, poor health, live in broken families or in criminal environment.

\section{Districts' assessment for the year 2016}

For the year 2016, we observe the value range of the socio-economic criteria similar to the one identified for the year 2011 (Figure 4), but the standard deviation calculated for the values of three LAU1 indicators exceed the others $\left(\mathrm{S}_{\mathrm{D} 1}=82.40 ; \mathrm{S}_{\mathrm{D} 2}=497.99\right.$; $\left.S_{\mathrm{D} 8}=120.27\right)$. The highest variability of the district indicators is identified for the $D_{4}$ indicator (share of inhabitants living in towns with more than 20,000 inhabitants). The same absolute dominance for the indicators defined for the NUTS3 regions is found for the $\mathrm{R}_{1}$ indicator (GDP per capita), which again has its structure influenced by Prague.

\section{Figure 4. Structure of the input indicators for the year 2016}
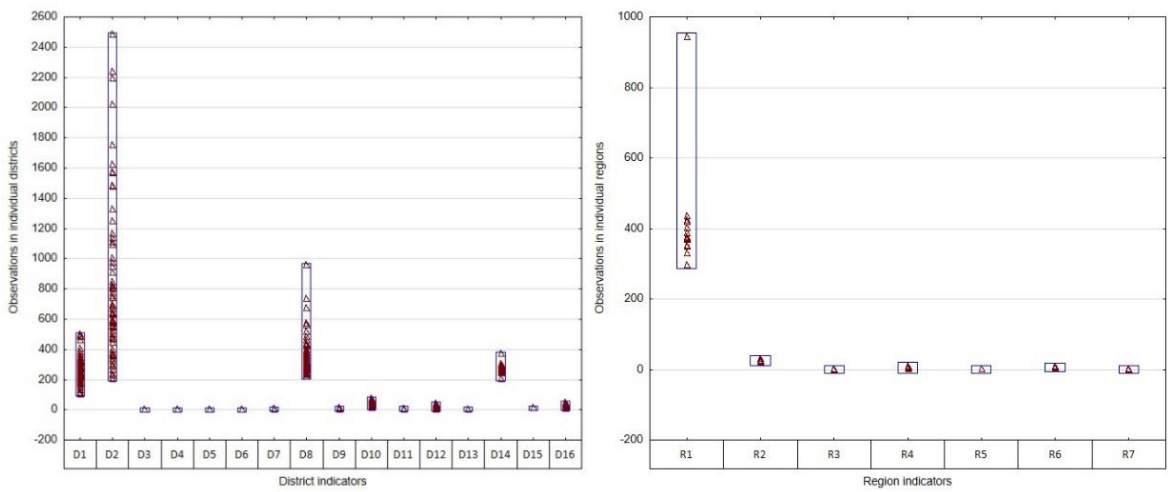

Source: own data processing

The complex results calculated using the CV-TOPSIS technique produce significant differences since the best district obtains 2,5 times higher assessment than the worst one. These significant differences are confirmed by other measures of variability $\left(\mathrm{s}_{2016}=0.09\right.$; $\left.\mathrm{v}_{2016}=16.19 \%\right)$ and the negative skewness $\left(\gamma_{2016}=-1.145\right)$. The causes can be found in the existence of outliers (Figure 5) representing the results for the districts of Most, Usti nad Labem, Decin, Chomutov, Karvina and Ostrava-City. 
Figure 5. Results of the CV-TOPSIS technique for the year 2016

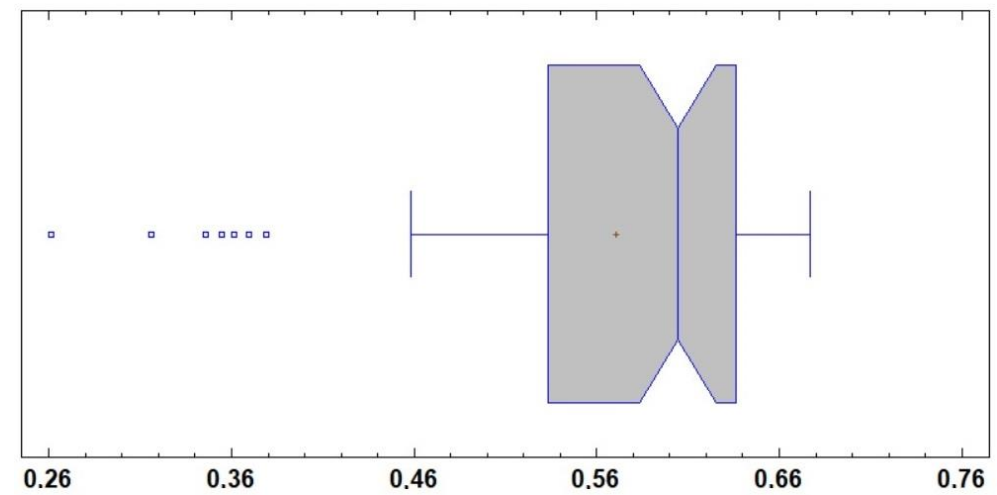

Source: own data processing

The differences identified in the assessment of the Czech districts are minimal and in most cases the differences between two districts with neighbouring ranks do not exceed $1.5 \%$ of $c_{i}$. The two exceptions are: Brno-city (rank 70) - Teplice (rank 71); Usti nad Labem (76) - Most (77) differing by $21 \%$. A positive change of the values of one indicator can lead to a more significant positive shift in the districts' assessment but only in the case of districts with higher ranks.

Figure 6. CV-TOPSIS technique results for the year 2016

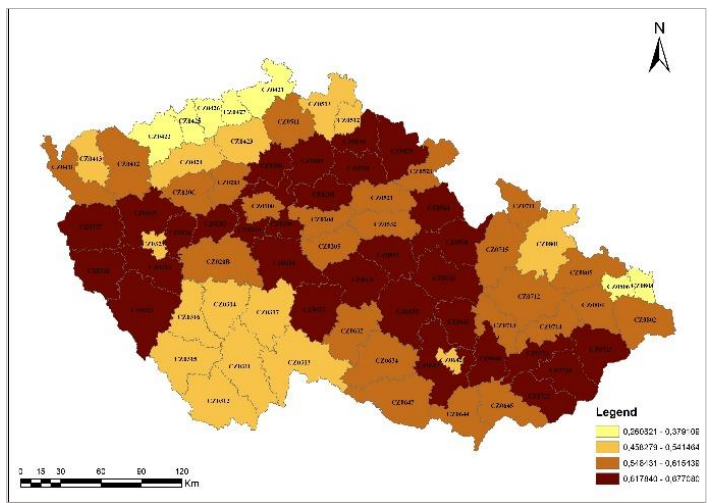

Source: own data processing

The districts of Rychnov nad Kneznou and Jicin (Hradec Kralove Region) belong to districts with higher $c_{i}$, similarly to the districts of Beroun and Benesov (Central Bohemian Region), see Figure 6. Pelhrimov (Vysocina Region) is the district with the highest $c_{i}$ calculated for the year 2016. All mentioned districts offer better socio-economic preconditions for a valuable life on the grounds that social exclusion or its preconditions are lower there than in other districts of the Czech Republic. The districts with the lowest $\mathrm{c}_{\mathrm{i}}$ are located in two NUT3 regions - the Usti Region and Moravian-Silesian Region, which conforms with the results found for the year 2011. In our opinion, the policy-makers and other public as well as private stakeholders have to pay higher attention to people living in social exclusion or facing its greater risks in both these regions. At least, they should 
strengthen the supply of individually targeted social prevention services which can immediately react on the worsening social situation of affected individuals.

Paired comparison of the districts' assessment done for the years 2011 and 2016

The paired comparison of the results found for the years 2011 and 2016 does not show statistically significant differences (see Figure 7). The results for both years have the same mean value $(\mathrm{U}=2572 ; \mathrm{p}=0.157)$ and the same overall structure $(\mathrm{K}-\mathrm{S}=0.182$; $\mathrm{p}=0.157)$. Minimal and non-significant differences are also visible through the comparison of the standard values $\left(s_{2011}=0.087 ; s_{2016}=0.092\right)$ and the ranges $\left(R_{2011}=0.366\right.$; $\mathrm{R}_{2016}=0.416$ ). We explain these results not only by the shorter time period between the two examined years but also by the minimal positive changes in socio-economic situation described by the defined criteria observed for NUT3 regions and LAU1 districts. These findings are not optimistic because the persistence of the current linked socio-economic problems, seen as the preconditions for social exclusion, can increase the number of individuals living in social exclusion.

Figure 7. Paired comparison of the CV-TOPSIS technique results, years 2011 and 2016

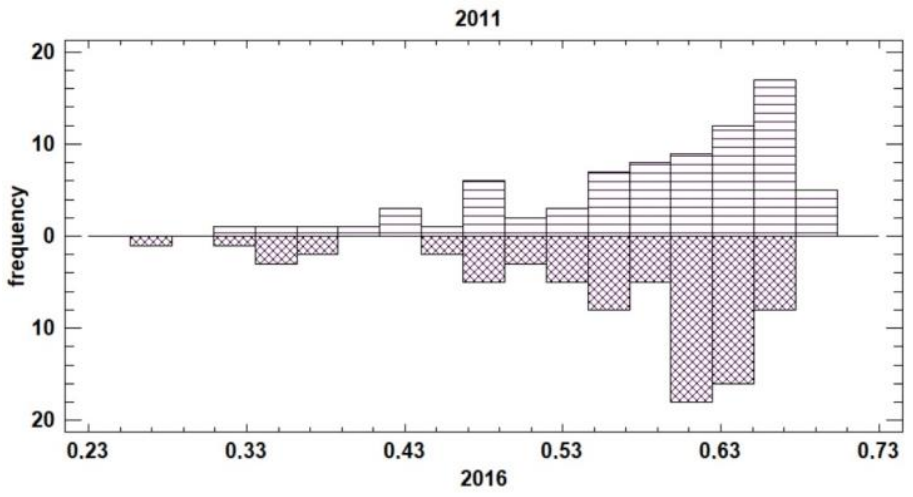

Source: own data processing

Table 3 illustrates that differences in absolute and relative terms cannot be associated. The district of Most is the case where the comparison of differences defined in absolute terms reveals the most significant decrease in the district's assessment $\left(\Delta c_{i}=-0.0934\right)$, but this change leads to a non-significant change in the overall rank (the lowest rank). The district of Tachov improves its overall position by 17 ranks in the year 2016, but its overall assessment is improved only by $2.04 \%$ in comparison with the year 2011 . We consider the district of Prague-West the ideal case because its worsening assessment is associated with the lowering rank. We prove the statistical relation between these two variables using the Kendall Rank Coefficient $\left(r_{K}=-0.655 ; p<0.01\right)$. The statistical significance confirms that the declining values of $c_{i}$ are connected to the lowering ranks in the districts' order. 
Table 3. The most significant changes in the year 2016

The most significant changes in absolute terms

\begin{tabular}{cccccc}
\multicolumn{2}{c}{ The most significant changes in absolute terms } & \multicolumn{3}{c}{ The most significant changes in ranking } \\
\hline 1. & $\Delta c_{i}$ & district & & $\Delta$ & district \\
\hline 2. & -0.09342 & Most & 1. & 21 & Prague-West \\
3. & -0.08009 & Usti nad Labem & 2. & -17 & Tachov \\
4. & -0.07676 & Decin & 3. & -16 & Jicin \\
5. & -0.07363 & Louny & 4. & -16 & Jesenik \\
6. & -0.06044 & Litomerice & 5. & 14 & Prague-East \\
7. & -0.05717 & Prague-West & 6. & -13 & Rychnov nad Kneznou \\
8. & -0.05083 & Teplice & 7. & 11 & Rakovnik \\
9. & -0.05048 & Chomutov & 8. & 11 & Domazlice \\
10. & -0.04842 & Plzen-South & 9. & -10 & Cheb \\
\hline
\end{tabular}

note: $c_{i}$ - relative distance to the Positive Ideal Solution

Source: own data processing

According to the spatial distribution of our results, we confirm spatial randomness in both years $\left(\mathrm{MI}_{2011}=0.0067 ; \mathrm{MI}_{2016}=0.0070\right)$ at the national level. However, if the spatial autocorrelation at the district level is evaluated with the use of LISA (Figure 8), we identify positive spatial autocorrelation due to the existence of areas in which districts with low and with high values of $c_{i}$ exist. In other words, we find the areas with lower or higher occurrences of social exclusion and its preconditions. These areas exist regardless of the districts' borders.

Figure 8. Moran's graph for the years 2011 and 2016

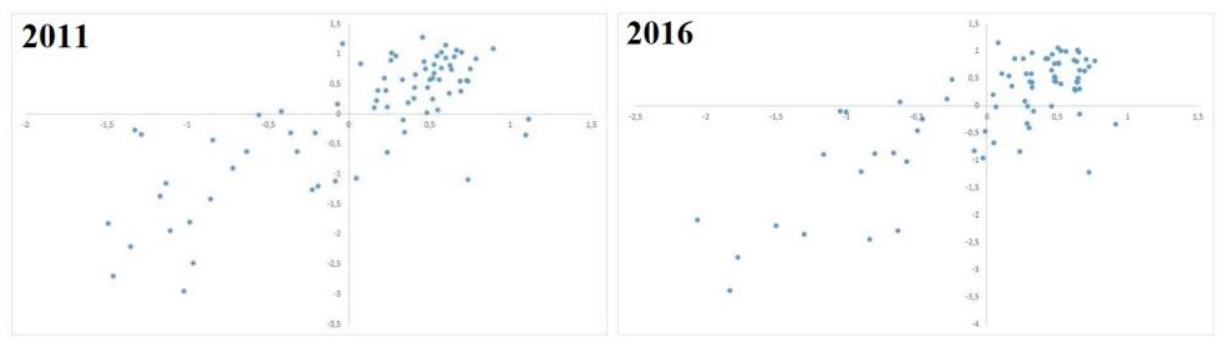

Source: own data processing

When we verify every point in Figure 8, we identify a negative spatial autocorrelation of the results of CV-TOPSIS technique for both years. For the year 2011, four districts are identified using the Z-score as the cold spots - districts with low values of $c_{i}$ and with similar neighbours. For the year 2016, eight districts are identified as cold spots. The identification of cold-spot areas is useful for the policy-makers because these findings can draw attention to the indirect spillover effects caused by positive changes in one district lying in the area. The majority of the cold spots is located in the northern part of the Czech Republic - in the Usti Region or Moravian-Silesian Region. It means that they are located in regions where districts with multiple disadvantage in terms of social exclusion and its preconditions exist (see Figure 9). This shows that the reduction or elimination of social exclusion or its preconditions in one district can have a positive impact on neighbouring districts and the overall effect of the improved situation will be higher thanks to these spillover effects. 
Figure 9. Identified spatial autocorrelation (cold spots) for the years 2011 and 2016

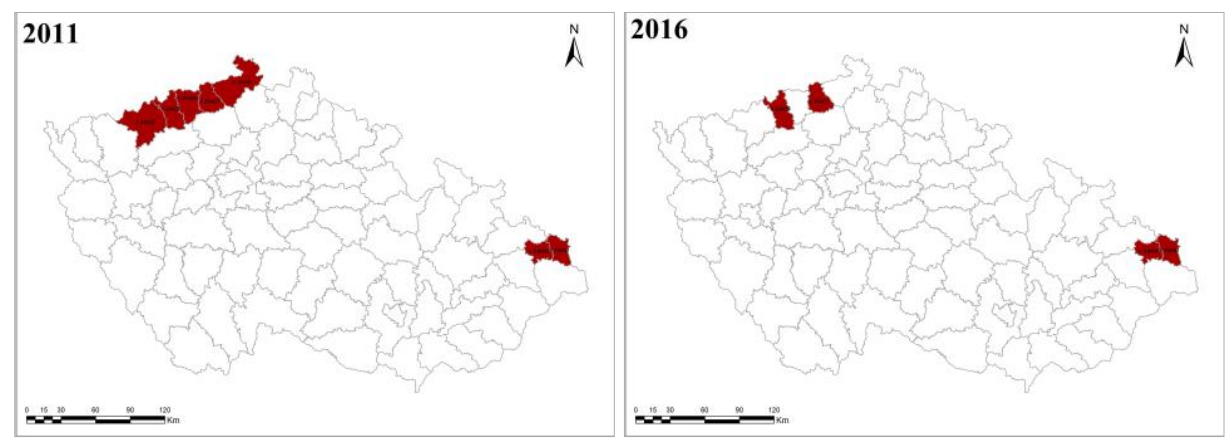

Source: own data processing

\section{Conclusion}

Social exclusion is considered by the European Union to be one of the fundamental problems that need to be dealt with. By the end of the year 2020, the number of socially excluded individuals had to be reduced significantly at the EU level - by 20 million according to the Europe 2020 strategy. The European Union declares that employment and education help to reduce monetary poverty, which is generally understood as the fundamental cause of social exclusion. The strategy also requests the commitment of public and private subjects to reduce social exclusion through concrete action at the level of EU Member States (European Commission, 2010). To meet the EU commitments concerning the social exclusion, various social programmes are used at the level of the EU Member States with the main responsibility on their national political authorities. In relation to the EU commitments, the Czech Social Inclusion Strategy for the years 2014-2020 considers employment together with equal access to all resources, rights, goods and services (especially housing, social protection, health care and education) to be a part of the general objectives within the social inclusion process.

Although the Europe 2020 strategy and the Czech Social Inclusion Strategy assign the pivotal roles in reduction of social exclusion and in its prevention (elimination of its preconditions) to employment and education, it is obvious these cannot improve the status of socially excluded individuals immediately. The role of employment and education should be seen especially in the prevention and reduction of social exclusion in longer time period. However, when social exclusion appears, public authorities should react immediately using the emergency means defined within the framework of the national social policy. Social prevention services or social transfers are designed to help the individuals living in the conditions of social exclusion immediately. To meet the needs of socially excluded individuals, it is necessary to offer social prevention services in the required form, kind and quality. The planning of the supply of social prevention services has to be based on the analysis of the occurrence of specific socio-economic preconditions for social exclusion (in terms of its causes and risks). At a community level, the analysis should deal with the specified set of socio-economic indicators, the assessment of which can reveal a combination of linked problems associated with social exclusion. 
The aim of the paper was to identify the occurrence of the preconditions for social exclusion in Czech districts revealed in the inter-district comparison based on the multi-criterial evaluation of the socio-economic situation in these districts. Based on the above-presented findings, we can claim that significant differences exist in the preconditions for social exclusion and possibilities of individuals to participate actively in the communities in the districts of the Czech Republic. Social exclusion and its preconditions in relative terms were revealed mainly in the districts lying in the Usti and Moravian-Silesian Regions. We also find that these differences were not reduced between the years 2011 and 2016 , and the districts affected by a combination of linked socio-economic problems were the same in both examined years, which we interpret in negative terms. Social risks that can lead to social exclusion of individuals living in the two above-mentioned NUT3 regions have not been eliminated with the currently applied social policy programmes. Our results also showed almost zero synergic effects when the positive impact of one district on other ones was considered. This finding revealed reduced effects of the activities of the state, territorial self-governments and private sector in the field of elimination of the preconditions for social exclusion. However, in the regions, where relative disadvantages in terms of social exclusion were revealed, some cold-spot areas were identified. Therefore, we can expect positive spillover effects if the socio-economic situation were to be improved in one district lying in these cold-spot areas.

With regard to our findings, we recommend to redesign and strengthen the supply of social prevention services in regions affected by social exclusion or identified with its higher risks. These services can meet the emergency needs of the socially excluded individuals in material and immaterial terms. Immaterial needs (such as access to education, health care or other civic amenities, and leisure activities such as culture or sport) can be met with the help of social prevention services provided in the form of ambulatory or field services targeted at the socially excluded individuals. These services can also reduce the intergenerational transfer of the behaviour increasing the risks of social exclusion when they are focused on children and youth. Therefore, we strongly recommend Czech policymakers to open up a public discussion on the redesign and modernization of the institutional, organizational and financial arrangement of social prevention services. They should be more individually targeted and better organized in the areas with persisting social exclusion, accumulation of its preconditions and its higher risks. The current forms of social policy programmes do not reduce nor eliminate them in a sufficient way.

Funding: Finalization of this paper was supported by the Student Grant Competition Project under Grant SP2021/51.

Disclosure statement: No potential conflict of interest was reported by the authors. 


\section{References}

BARNES, H., NOBLE, M., WRIGHT, G., DAWES, A. (2009). A Geographical Profile of Child Deprivation in South Africa. Child Indicators Research, 2(2), 181-199. DOI: 10.1007/s12187-008-9026-2.

CHAKRAVARTY, R. S., D' AMBROSIO, C. (2006). The Measurement of Social Exclusion. The Review of Income and Wealth, 52(3), 377-398. DOI: 10.1111/j.14754991.2006.00195.x.

DALY. A., D'SOUZA, G., MIRANTI, R. (2016). Youth Social Exclusion in Australian Communities: A New Index. Social Indicators Research, 128(2), 635-660. DOI: 10.1007/s11205-015-1048-9.

DEAN, H. (2016). Poverty and social exclusion. In H. Dean \& L. Platt (Eds), Social Advantage and Disadvantage (pp. 3-24). Oxford: Oxford University Press.

ESTIVILL, J. (2003). Concepts and strategies for combating social exclusion: An overview. Geneva: International Labour Organization.

EUROPEAN COMMISSION (2020a). People at Risk of Poverty or Social Exclusion [online]. Retrieved 2020-12-11 from https://ec.europa.eu/eurostat/web/products-datasets/-/t2020_50.

EUROPEAN COMMISSION (2020b). Eurostat. Data [online]. Retrieved 2020-12-10 from https://ec.europa.eu/eurostat/data/database.

EUROPEAN COMMISSION (2019). Access to high-quality social services [online]. Retrieved 2020-03-09 from https://ec.europa.eu/social/main.jsp?catId=1169\&langId=e.

EUROPEAN COMMISSION (2010). Europe 2020. A Strategy for Smart, Sustainable and Inclusive Growth [online]. Retrieved 2021-02-25 from https://ec.europa.eu/eu2020/pdf/COMPLET\%20EN\%20BARROSO\%20\%20\%20007\%20-\%20Europe $\% 202020 \% 20-\% 20 \mathrm{EN} \% 20$ version.pdf.

HARDING, A., DALY, A., MCNAMARA, J., YAP, M. (2009). Australian children at risk of social exclusion: a spatial index for gauging relative disadvantage. Population, Space and Place, 16(2),135-150. DOI: 10.1002/psp.53.

LEVITAS, R. (1998). The inclusive society? Social exclusion and new labour. Basingstoke: Palgrave Macmillan.

MAREŠ, P., SIROVÁTKA, T. (2008). Sociální vyloučení (exkluze) a sociální začleňování (inkluze) - koncepty, diskurz, agenda. Sociologický časopis/Czech Sociological Review, 44(2), 271-294.

MCCRYSTAL, P., HIGGINS, K., PERCY, A. (2001). Measuring social exclusion: a lifespan approach. Radical Statistics, 76, 3-14.

MERTL, J. (2007). Přistupy k hodnoceni efektivnosti sociálních služeb v národním hospodářství. Prague: Research Institute for Labour and Social Affairs.

MILAR, J. (2007). Social Exclusion and Social Policy Research: Defining Exclusion. In D. Abrams, J. Christian \& F. Gordon D (Eds), Multidisciplinary Handbook of Social Exclusion Research Chichester (pp. 1-15). NJ: John Wiley \& Sons. 
MINISTRY OF LABOUR AND SOCIAL AFFARS. MLSA (2014). Social Inclusion Strategy (2014-2020) [online]. Retrieved 2021-02-25 from https://www.mpsv.cz/documents/20142/953611/Strategie_EN.pdf/8a1e1028-854e-8c22-5266-047867de4272.

OROYEMI, P., DAMIOLI, G., BARNES, M., CROSIER, T. (2009). Understanding the risks of social exclusion across the life course: Families with Children. Bristol: National Centre for Social Research.

ROOM, G. (1995). Poverty and social exclusion: the new European agenda for policy and research. In G. Room (Ed), Beyond the Threshold: The Measurement and Analysis of Social Exclusion (pp. 1-9). Bristol: Polity Press.

SEN, A. (2000). Social Exclusion: Concept, Application, and Scrutiny. Manila: Office of Environment and Social Development.

SILVER, H. (1994). Social exclusion and social solidarity: Three paradigms. International Labour Review, 133(5-6), 531-578.

SLÁVIK, V., GRÁC, R., KLOBUČNÍK, M. (2011). Priestorová autokorelácia - metóda vymedzovania a klasifikácie regiónov v kontexte sociálno-ekonomickej regionalizácie Slovenskej republiky. Sociology, 43(2), 183-204.

SOCIAL EXCLUSION UNIT. (2001). Preventing Social Exclusion. [online]. Retrieved March 10, 2020, from http://www.bris.ac.uk/poverty/downloads/keyofficialdocuments/Preventing\%20Social\%20Exclusion.pdf.

VAVREK, R. (2019). Evaluation of the Impact of Selected Weighting Methods on the Results of the TOPSIS Technique. International Journal of Information Technology \& Decision Making, 18(6), 1821-1843. DOI: 10.1142/S021962201950041X.

VAVREK, R., BEČICA, J. (2020). Capital City as a Factor of Multi-Criteria Decision Analysis-Application on Transport Companies in the Czech Republic. Mathematics, 8, 1765. DOI: $10.3390 /$ math 8101765.

VÍŠEK, P., PRŮŠA, L. (2012). Optimalizace sociálních služeb. Prague: Research Institute for Labour and Social Affairs. 